\title{
Analysis of Plant Diversity of Iranian Oak Ecosystem Using Multivariate Statistical Methods (Case Study: Javanrod City-Kermanshah City)
}

\author{
Ali Khansari1, Nematollah Khorasani1, Mahdi Ramezani ${ }^{1}$, Bahman Shams Esphandabad ${ }^{2}$ \\ ${ }^{1}$ Department of Environmental Science, Science and Research Branch, Islamic Azad University, Tehran, Iran \\ ${ }^{2}$ Department of Environmental Science, Arak Branch, Islamic Azad University, Arak, Iran \\ Email: *m_ramezani@srbiau.ac.ir
}

Received 19 July 2016; accepted 18 August 2016; published 22 August 2016

Copyright (C) 2016 by authors and Scientific Research Publishing Inc.

This work is licensed under the Creative Commons Attribution International License (CC BY).

http://creativecommons.org/licenses/by/4.0/

c) (i) Open Access

\begin{abstract}
In this research diversity of plant species in ecosystem units in an oak habitat of Zagros forests was investigated. For this purpose data on vegetation in 60 sample plots were recorded. Multivariate statistical methods were used to determine ecosystem units. Combined methods of cluster analysis and two-way indicator species analysis were used for determining ecosystem units. To investigate the diversity gradient between ecosystem units, different methods of ordination including principal component analysis and detrended correspondence analysis were used. According to analysis 4 ecosystem units were determined. The diversity was calculated by using Simpson, Shanon, Macintosh, Margalof and Manhanic. Also the Manhanik index has created the most distinction among groups in comparison to other indexes.
\end{abstract}

\section{Keywords}

Plant Species, Ecosystems, Oak Habitats, Zagros

\section{Introduction}

Biodiversity is essential in human life, economic issues, sustainability and ecosystem performance [1]. Only small areas of the earth have the capacity to maintain many species. Comparative measurements of plant species diversity and ecosystem performance in relation with environmental factors can be helpful in response with ba-

*Corresponding author.

How to cite this paper: Khansari, A., Khorasani, N., Ramezani, M. and Esphandabad, B.S. (2016) Analysis of Plant Diversity of Iranian Oak Ecosystem Using Multivariate Statistical Methods (Case Study: Javanrod City-Kermanshah City). Open Journal of Ecology, 6, 545-553. http://dx.doi.org/10.4236/oje.2016.69052 
sic questions for ecosystem management (for example, long-term reaction of vegetation to dysfunction in the system and identifying appropriate signs for evaluate system health) [2] [3].

The forest managers require information about features of forest habitat in order to make right decisions with proper selection and better management of operations [4]. Habitat characteristics are properly reflected in the vegetation and indicators of habitat quality can be found in vegetation. Although we can classify habitat characteristics indicators by means of some few plants, the presence or absence of these species depends on the accident, history of the forest, or competition conditions. Resolving this issue is possible by using ecological species groups which have similar environmental needs. A group of species that are repeated in similar ecologic conditions are named ecologic species groups [5]. Methods that are considered in non-classical statistics can be divided into two general categories: classification methods and ordination methods of habitat. Classification method is developed on the basis of sociological theory and ordination method is developed on the basis of Gradient analysis [6]. Gradient analysis is of direct and indirect types. In direct type changes in vegetation are studied directly through study environmental factors and in indirect type changes in vegetation are studied apart from environmental factors while environmental factors are investigated only in the data interpretation step. The major methods of vegetation ordination include Principal Component Analysis, Detrended Correspondence Analysis and Canonical Correspondence Analysis [7]. One of the methods to classify vegetation is Two-Way Indicator Species Analysis which in fact is one of the Divisive Techniques. Oak forests of the West of Iran with its unique diversity and having multiple plant communities are considered as the most important natural ecosystems [8] [9]. The oak forests of the west are among the most important biologic resources that have special importance in terms of size, plant and animal species, byproducts of forest genetic resources, the understory pastures, socio-economics, etc. [10].

With the development of computer science and as a result of multivariate numerical methods in vegetation classification processes, attempts has done to reduce the subjectivity factor in describing the vegetation [6]. Also the development of computers and the possibility of heavy numerical processing provide the opportunity to take advantage of the new processing methods and calculations.

\section{The Study Area}

The study area is located in the forest in the North West province of Javanrood city from Kermanshah province. The study habitats were selected with an area of 100 hectares (Figure 1, Figure 2). In general different air masses in warm and cold sessions of the year influence the west of Iran from the northwest. Most of the rainfall in these areas is in the form of snow $44.9 \%$ in winter, $29.5 \%$ in autman, $25.5 \%$ in spring and only 0.1 rainfall in summer takes place. The status temperature is variable. Seasonal distribution of temperature is: the spring 14.8 degree, summer 27.7 degree, autumn 10.6 degree, winter 2.5 degree (Kermanshah, Watershed Management).

The nearest stations to watershed were used to describe the climate of the region. The number of statistical years is considered. The regional climate based on Emberger method is semi-humid and cold (Kermanshah, Watershed Management). The study area is located in the Zun region of the Zagros Mountain. Zun Zagros is a region of Iran which is located in the west of the main fault of Zagros. This Zun is located as a narrow strip between Zun of Sanandaj and Sirjan and folded Zagros. The most ancient layers of rock units in the region consisted of layers of rhyolite and Guinness with low expansion and Precambrian age. Rock samples which were exposed in the region were gathered with the field survey which all belonged to the sedimentary rocks.

\section{Material and Methods}

\subsection{Determination Method of Ecosystem Units}

In this research initially by using topographical maps with scale of $1 / 25,000$, the maps of slope classes, range of direction and the classes above the sea level on the floors match with the habitat conditions of the study, were prepared. After combining these maps, the map of land form unit obtained. For doing next steps of the research, at the first vegetation types on the base map was determined by using forest workflows for each habitat. Then by adjusting the map of vegetation types with obtained physiographic map, the main units of the work was determined. the parameters related to mass trees were include: tree height, crown diameter, diameter at breast height, diameter at breast height Search groups and the number of search groups for obtaining curve parameters of altitude in relation with diameter, the area of crown cover, distribution in diameter classes, cross section at breast 


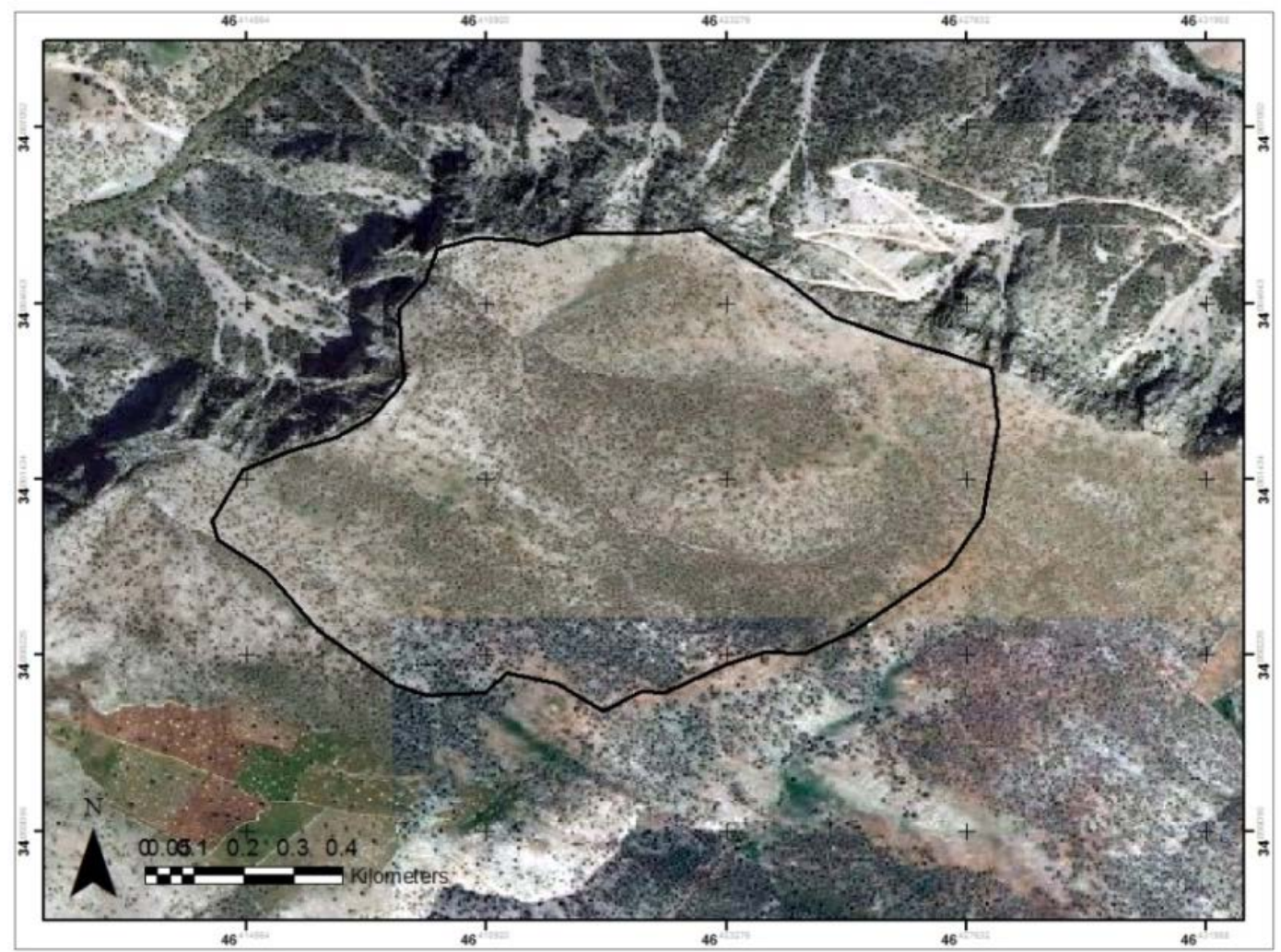

Figure 1. Aerial photographs and boundary of the study area.

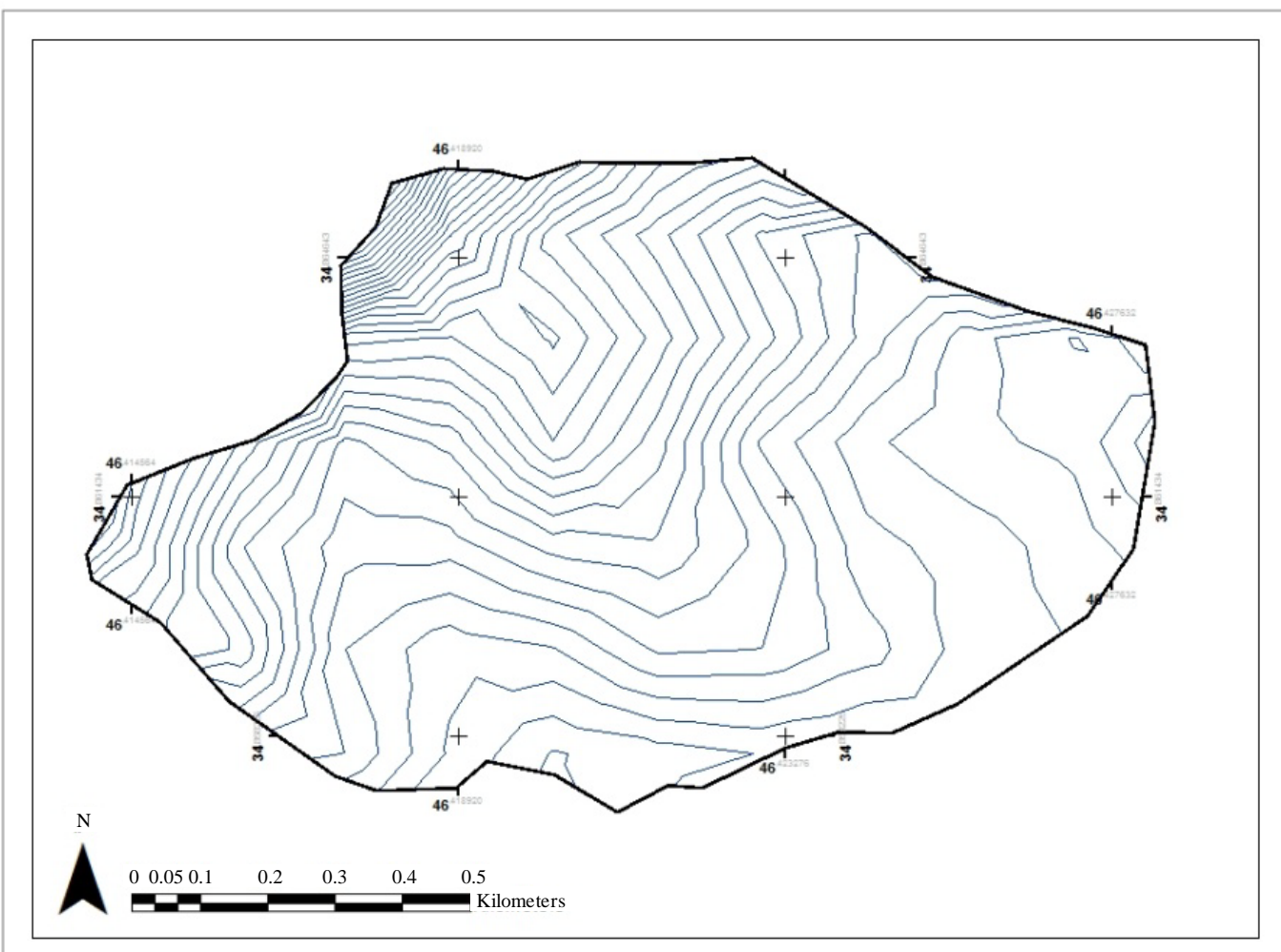

Figure 2. Topographic map of the study area. 
in hectare. Sampling of all species of tree, shrub and herbaceous, was done in the main section. The specie and abundance were considered as criteria measures of vegetation. The area of each of sample components were considered 256 square meters which this area obtained through drawing the curve of area-species [11]. Totally 60 samples were collected. For taken samples, firstly coordinates of the center of each sample was interred manually in GPS and from the navigation option the navigation carried out toward the center of sample. The movement of expert continued until reaching to 1 meter range.

\subsection{The Determination Method of Index Species in Ecosystem Units}

The methods of Dufrene and Legendre (1997) were used for determine index species in ecosystem units (which was based on a combination of two-way index species analysis methods (TWINSPAN) and cluster analysis) [12].

-Calculate the relative abundance of a particular species compared to the abundance of species in the whole group which usually indicates as percent;

$$
R A_{j k}=\frac{X_{k j}}{\sum_{k=1}^{g} X_{k j}}, \quad X_{k j}=\frac{\sum_{i=1}^{n_{i}} a_{i j k}}{n_{k}}=X_{k j}
$$

$X_{k j}$, the mean of abundance the $j$ species in $k$ group,

$a_{i j k}$, abundance $j$ species in sample part of I from $k$ group,

$n_{k}$, the number of sample section in $k$ group,

$g$, the whole number of groups,

$R A_{j k}$, relative abundance of $j$ species in $k$ group.

-Calculate the relative abundances of species in each group are shows as a percent of sample portions in each group which contains it:

$$
R F_{j k}=\frac{\sum_{i=1}^{n_{i}} b_{i j k}}{n_{k}} \ldots
$$

$R F_{j k}$, the relative abundance of $j$ species in $k$ group,

$b_{i j k}$, the abundance of $j$ species in sample plot of $k$ group,

$n_{k}$, the number of sample plot in $k$ group.

-combine the above equations and calculate the index value: $I V_{j k}=R A_{J K} \times R F_{J K} \times 100$.

-determine the highest index value for each species in each group.

-evaluate meaningfulness of maximize value index by using Monte Carlo test.

\subsection{Biodiversity Indexes}

For compare biodiversity in the group of ecologic species the indexes of Simpson, 1949, Margalof richness index, 1958, the richness Menhenic index, 1964, Shannon and Wiener, 1949 index and McIntosh, 1967 index were used.

Simpson, 1949 index

$$
1-D=1-\sum_{i=1}^{S} \frac{n_{i}\left(n_{i}-1\right)}{N(N-1)}
$$

Margalof richness index, 1958

$$
R_{1}=\frac{S-1}{\ln (N)}
$$

The richness Menhenic index, 1964

$$
R_{2}=\frac{S}{\sqrt{N}}
$$

Shannon and Wiener, 1949 index 


$$
\begin{gathered}
H^{\prime}=-\sum_{i=1}^{S}\left(p_{i}\right) \times\left(\ln p_{i}\right) \\
H^{\prime}=-\sum_{i=1}^{S}\left(p_{i}\right) \times\left(\log _{2} p_{i}\right)
\end{gathered}
$$

McIntosh, 1967 index

$$
U=\sqrt{\sum_{i=1}^{S} n_{i}^{2}}
$$

The number of people in the I species in the frame: $n_{i}$,

The whole people in the frame: $N$,

The number of species: $S$,

The ratio of people with abundance I species which is expressed according to the whole vegetation: $p_{i}$,

Biological diversity index of Simpson: $1-D$,

Margalof richness index: $R_{1}$,

The richness Menhenic index: $R_{2}$,

Simpson richness index: $H^{\prime}$,

The diversity McIntosh index: $U$.

\section{Results}

Indicator Species Analysis results:

For analyzing relationship between vegetation and environment and showing th value of each species in different environmental conditions, according to final grouping, for each species in each group the value of index is determined by Dufrene and Legendre method (1997) (Table 1).

\subsection{The Results of Unilateral Variance Decomposition of Indexes in Ecosystem Units}

The results of unilateral variance decomposition indicate that all indexes despite of Margalof index in different ecosystem units have meaningful statistical difference (Table 2). According to F computing the Manhanik index has shown the most difference in the ecosystem units.

After significant difference in the indices of different ecosystem by using monolateral variance decomposition the Dankan was used to separate comparison of ecosystem units (Table 3).

Mean comparisons were performed using Duncan test at $5 \%$ level. There is no meaningful difference in each column between means that their right letter is common.

According to conducted analysis of variance (Duncan), the Simpson in the unit 2 has the meaningful difference with other units and the mean of unit 2 is more than other units yet the units of 1,3 and 4 had no meaning- ful difference with each other. Macintosh index in unit 2 is more than other units and unit 2 has the higher average in comparison to unit 3. but unit 1 has no meaningful difference with unit 4. According to Manhanic index only unit 4 has meaningful difference with other units (Tables 3-5).

\subsection{Describe Ecosystem Units}

Finally, four ecological groups were separated, the characteristics of which are as follows

First ecosystem unit: the tree species index of this unit is Pyrus syriaca and Gramineous species index are as follows:

Caltha palustris, Helianthemum ledifolium, Hippocrepis bisiliqua, Hypericum scubrum,

Loronilla scorpioides, Marrubium vulgare, Medicago radiate, Medicago rigidula, Pisum sativum, Sameraria stilophora, Silene conoidea, Trifolium ravense, Trifolium dasyorum, Trifolium pilulare, Trifolium tomentosum.

Sample plots located in this unit has mean percent slope (4.1, 65.3). the Manhanic richness index is $(0.89 \pm$ 0.07), this unit includes 19.00 percent of the whole sample plots.

The second ecosystem unit: the tree species index of this unit is Quercus infectoria and its Gramineous species index are as follows: 
Table 1. The value of index for vegetation species in each group, p (the probability of I type error according to Monte Carlo test).

\begin{tabular}{|c|c|c|c|}
\hline Vegetation species names & The index value & group & $\mathrm{P}$ \\
\hline Alyssum maginatum & 28.7 & 4 & 0.01 \\
\hline Asperula arvensis & 27.4 & 4 & 0.009 \\
\hline Bromus tectrum & 33.2 & 3 & 0.02 \\
\hline Bromus tomentellus & 35.1 & 4 & 0.04 \\
\hline Caltha palustris & 26.9 & 1 & 0.03 \\
\hline Cardinia orientalis & 46.5 & 2 & 0.03 \\
\hline Cerastium inflatum & 28.0 & 3 & 0.03 \\
\hline Eragrostic pilosa & 27.3 & 4 & 0.03 \\
\hline Eromopoa persica & 39.6 & 3 & 0.001 \\
\hline Fumaria villanti & 27.4 & 4 & 0.01 \\
\hline Helianthemum ledifolium & 33.3 & 1 & 0.04 \\
\hline Hippocrepis bisiliqua & 26.8 & 1 & 0.04 \\
\hline Hypericum scubrum & 26.9 & 1 & 0.03 \\
\hline Lallementia iberica & 28.6 & 4 & 0.04 \\
\hline Legucia speculum & 27.3 & 3 & 0.03 \\
\hline Lens orientali & 35.0 & 3 & 0.04 \\
\hline Loronilla scorpioides & 27.0 & 1 & 0.04 \\
\hline Marrubium vulgare & 26.8 & 1 & 0.04 \\
\hline Medicago radiata & 27.2 & 1 & 0.01 \\
\hline Medicago rigidula & 26.8 & 1 & 0.04 \\
\hline Pisum sativum & 27.1 & 1 & 0.04 \\
\hline Poa bulbosa & 32.8 & 3 & 0.004 \\
\hline Pyrus syriaca & 26.9 & 1 & 0.04 \\
\hline Quercus Infectoria & 31.7 & 2 & 0.04 \\
\hline Quercus brantii & 36.4 & 3 & 0.01 \\
\hline Ranunculus arvensis & 27.0 & 3 & 0.04 \\
\hline Ranunculus falcata & 27.8 & 3 & 0.01 \\
\hline Rochelia dispermum & 28.2 & 3 & 0.02 \\
\hline Rosa caniana & 27.0 & 4 & 0.03 \\
\hline Sameraria stilophora & 27.0 & 1 & 0.04 \\
\hline Scandix stellata & 31.7 & 4 & 0.002 \\
\hline Silene conoidea & 26.9 & 1 & 0.02 \\
\hline Teniaterum crinitum & 36.0 & 2 & 0.001 \\
\hline Trifolium arvense & 48.9 & 1 & 0.03 \\
\hline Trifolium dasyorum & 34.1 & 1 & 0.01 \\
\hline Trifolium pilulare & 38.4 & 1 & 0.003 \\
\hline Trifolium tomentosum & 31.5 & 1 & 0.002 \\
\hline Trigonella sprunarriana & 27.2 & 2 & 0.01 \\
\hline
\end{tabular}


Table 2. Results of analysis variance indexes in ecosystem units.

\begin{tabular}{cccccc}
\hline & Simpson & Shanonn & Mocintosh & Margalof & Manhanic \\
\hline Computing F value & 2.74 & 2.22 & 8.38 & 1.02 & 8.98 \\
The value of P & $0.05^{*}$ & $0.08^{*}$ & $0.01^{* *}$ & 0.39 & $0.01^{* *}$ \\
\hline
\end{tabular}

Table 3. The average indexes of diversity in ecological groups.

\begin{tabular}{cccc}
\hline Ecosystem units & Simpson & Mac intosh & Manhanic \\
\hline Unit 1 & $0.87^{\mathrm{b}}$ & $28.32^{\mathrm{b}}$ & $0.90^{\mathrm{b}}$ \\
Unit 2 & $0.90^{\mathrm{a}}$ & $34.34^{\mathrm{a}}$ & $0.96^{\mathrm{b}}$ \\
Unit 3 & $0.88^{\mathrm{b}}$ & $23.24^{\mathrm{c}}$ & $0.97^{\mathrm{b}}$ \\
Unit 4 & $0.87^{\mathrm{b}}$ & $29.41^{\mathrm{b}}$ & $1.30^{\mathrm{a}}$ \\
\hline
\end{tabular}

Table 4. Correlation between the axis of DCA (plots) and diversity indices.

\begin{tabular}{ccc}
\hline Diversity indices & Axis 1 & Axis 2 \\
\hline Indices McIntoch & $-0.46^{* *}$ & $\mathrm{~ns} 0.12$ \\
Indices Simpson & $-0.50^{* *}$ & $\mathrm{~ns} 0.10$ \\
Indices Margalef & $-0.55^{* *}$ & $\mathrm{~ns} 0.12$ \\
Indices Menhenic & $-0.53^{* *}$ & $\mathrm{~ns} 0.14$ \\
Indices Shanon & $-0.48^{* *}$ & $\mathrm{~ns}-0.16$ \\
\hline
\end{tabular}

Indicates meaningfulness of correlation in the level of 0.05 , **indicates the meaningfulness in the 0.01 level and ns is shows not meaningfulness.

Table 5. Correlation between PCA axis (sample plots) and diversity indexes.

\begin{tabular}{ccc}
\hline Indices & Axis 1 & Axis 3 \\
\hline Indices McIntoch & ns 0.06 & $0.37^{* *}$ \\
Indices Simpson & ns -0.01 & $0.36^{* *}$ \\
Indices Margalef & ns 0.04 & $-0.28^{*}$ \\
Indices Menhenic & ns 0.09 & $0.23 \mathrm{~ns}$ \\
Indices Shanon & ns 0.19 & $0.27^{*}$ \\
\hline
\end{tabular}

*Indicates meaningfulness of correlation in the level of 0.05 , ** indicates the meaningfulness in the 0.01 level and ns is shows not meaningfulness.

Teniaterum crinitum, Cardinia orientalis, Trigonella sprunarriana

Sample plots located in this unit have the mean slope percent (29.4 \pm 6.2$)$. the mean of Manhanic richness index is $(0.98 \pm 0.06)$. This unit includes 29.3 percent of whole sample plots.

Third ecosystem unit: the tree species index of this unit is Quercus brantii and its Gramineous species index are as follows:

Bromus tectrum, Cerastium inflatum, Eromopoa persica, Legucia speculum, Lens orientali, Poa bulbosa, Ranunculus arvensis, Ranunculus falcata

Rochelia dispermum

Sample plots located in this unit have the mean slope percent $(50.1 \pm 3.7)$. the mean of Manhanic richness index of this unit is $(0.97 \pm 0.04)$.

This unit includes 33.5 percent of the whole sample plots.

The fourth ecosystem unit: this unit has lack of tree index unit and its shrub species is Rosa caniana which is 
index in this group. And their gramineous species indexes are as follows:

Alyssum maginatum, Asperula arvensis, Bromus tomentellus, Eragrostic pilosa Fumaria villanti, Lallementia iberica, Scandix stellata

Sample plots located in this unit have the mean slope percent (61.2 \pm 2.0$)$. the mean of Manhanic richness index is $(1.30 \pm 0.06)$. This unit includes 18.2 percent of whole sample plots.

The axis 2 indicates the soil state of habitat. Because species such as Bromus tomentellus, Pistacia atlantica, Teniaterum crinitum which are located in the most distal section of axis 2 indicates the rocky area and full steep and they would presence more in the upper regions of the forest. But species that located in the bottom of axis 2 such as: Quercus infectoria, Eromopoa persica, Veleziz rigida select the regions down the slopes with deeper soil and more common valleys.

The axis 2 indicates results of category with the arc measured match analysis method for sample plots. The right direction of axis1 is species unit Crataegous pontica and its left direction is Quercus persica, on the up side of axis unit located Pistacia atlantica and in the downward of axis unit located Quercus infectoria.

\section{Discussion}

The importance of vegetation in assessing the relative fertility of the forest has a long history of ecology. But also there are limitations for using herbaceous in classifying vegetation. For example, a few key factors that are telling are used in classification [13]. The single species criteria have some shortages: first only a very small portion is considered herbaceous [13] [14]. Although there are many methods for classifying forest lands [15] [16], all of them have failed to show fairly the importance of communication between the components of an ecosystem. Because some of groupings just use one component alone just like soil or vegetation [17]. But another alternative that can be used to assess habitat quality is index species which can distinguish ecosystem units in combination with environmental units. Ecosystem units show the effects of multiple gradients (Multiple factor gradients) [18]. In this case, the presence of plants in habitat due to multiple interactions between physical and biotic factors is assumed [19]. Multi-factor and multivariate methods are now widely used in ecological classification systems. Multivariate methods category, classification and discriminate analysis have been used to determine the ecological species groups [20]. Based on the results it can be seen that fairly acceptable concordance between results obtained using the two methods. Accordingly species such as: Trifolium arvense, Myosotis refracta, Cardinia orientalis, Hetrantelium piliferum, can be seen on clay soils in the foothills and apparently demand more moisture. Trifolium arvense species in the forests of oak coppice will be present on calcareous rock. Ecologic ranges of herbaceous species in the gradient of moisture and nutrients are more limited than understory trees which may be attend in wider range in the forest [19].

On the other hand species such as Lens orientali, Ziziphora capitata, Poa bulbosa, Quercus brantii, Bromus tectorum, Erodium cicatarium are seen in other units. Iran oak species are placed in dry places and the southeast directions [10]. The species of Poa bulbosa is presented in the mountains with limestone cliffs and on dry slopes and rocky areas. The presence of Ziziphora capitata species has reported in arid and open, rocky areas and rock outcrops regions. The obtained results indicate meaningful correlation between environmental factors of height from sea level, Simpson index, Margalof index, Manhanic index, Shanon-Winner index and Macintosh index, which are consistent with conducted researches.

The concept of plant ecological groups has risen based on a unified theory of society and the idea of vegetation as mosaic [21]. Various methods ranging from one-factor or multi-factor is used for forest classification. Today, the classification of vegetation and its importance in the management of forest habitats has been one of the main topics [19]. But modern methods of classification were performed on the basis of objective methods. Such that researchers by applying this research usually reach to the same results [7]. Therefore, in this study a combination of different methods of numerical classification was used to finally be able to reach a comprehensive classification in terms of ecologic interpretation. The Dufrene and Legendre 1997 method were used for determining indicator species for final ecosystem units.

The first ecosystem unit of tree species index Pyrus syriaca and related Gramineous species represents the intermediate condition compared to other groups.

The second ecosystem unit of tree species index Quercus infectoria and related Gramineous species represents: humid condition, high species diversity, lower slopes, lower height from sea level.

The third ecosystem unit of tree species index Quercus brantii and Gramineous species indicates: regions 
with lower humid and unsavory Adaphic condition.

The fourth ecosystem unit that lacks tree species index and shrub species of Rosa caniana is index in this group. The Gramineous species represents slopes and wet areas.

Higher levels of species diversity in the tannic ecosystem unit can be due to better soil conditions and humidity. Of course in study of Manhanic index in units we can see that the unit 4 has the highest value of this index.

In this study by considering different results obtained from different parts, we can say that physiographic factors, especially slope percent and altitude above the sea level, had efficient role in separation ecosystem units. Ghalanda Aishi (2003) stated that the most physiographic factors affecting ecological groups were slope. Of course the absence of environmental factor among the factors could be due to the limited geographical aspects in the study area.

\section{References}

[1] Singh, J.S. (2002) The Biodiversity Crisis: A Multifaceted Review. Current Science, 82, 499-500.

[2] Metzger, K.L., Coughenour, M.B., Reich, R.M. and Boone, R.B. (2005) Effects of Seasonal Grazing on Plant Species Diversity and Vegetation Structure in a Semi-Arid Ecosystem. Journal of Arid Environments, 61, 147-160. http://dx.doi.org/10.1016/j.jaridenv.2004.07.019

[3] Pueyoa, Y., Aladosa, C.L. and Ferrer-Benimeli, C. (2006) Is the Analysis of Plant Community Structure Better than Common Species-Diversity Indices for Assessing the Effects of Livestock Grazing on a Mediterranean Arid Ecosystem? Journal of Arid Environments, 64, 698-712. http://dx.doi.org/10.1016/j.jaridenv.2005.06.016

[4] Harrington, A.C. (1966) A Method of Site Quality Evaluation for Red Alder. United Department of Agriculture, 19 p.

[5] McNab, W.H., Browing, S.A., Simon, S.A. and Fouts, P.E. (1999) An Unconventional Approach to Ecosystem Unit Classification in Western North Carolina, USA. Forest Ecology and Management, 114, 405-420. http://dx.doi.org/10.1016/S0378-1127(98)00371-5

[6] Whittaker, R.H. (1962) Classification of Natural Communities. Botanical Review, 28, 1-239. http://dx.doi.org/10.1007/BF02860872

[7] Basiri, R. (2003) Ecological Study of Habitat Region of Quercus libani Oliv, Analyzing Environmental Factors in Marivan. Ph.D. Thesis, Tarbiat Modarres University, Noor University, 123.

[8] Mohadjer, M.R. (2012) Silviculture. University of Tehran Press, Tehran, 418 p.

[9] Jazirehi, M.H. and Rostaaghi, E.M. (2003) Silviculture in Zagros. University of Tehran Press, Tehran, 560 p.

[10] Fattahi, M, et al. (2000) Zagros Forest Management. Publication Research Institute of Forests and Rangelands, 471.

[11] Cain, S.A. (1995) Manual of Vegetation Analysis. Harper and Row, New York, 325 p.

[12] Metz, J.J. (1997) Vegetation Dynamic of Several Little Disturbed Temperate Forests in East Central Nepal. Mountain Research and Development, 17, 333-351. http://dx.doi.org/10.2307/3674023

[13] Daubenmire, R.F. (1952) Forest Vegetation of Northern Idaho and Adjacent Washington, and It's Bearing on Concepts of Vegetation Classification. Ecological Monographs, 26, 131-154. http://dx.doi.org/10.2307/1943287

[14] Rowe, J.S. (1956) Use of Undergrowth Species in Forestry. Ecology, 37, 461-473. http://dx.doi.org/10.2307/1930168

[15] Shanon, C.E. and Weaner, A. (1949) The Mathematical Theory of Communication. University of Illinois Press, Champaign, $350 \mathrm{p}$.

[16] Barnes, B.V., Pregitzer K.S., Spies T.A. and Spoonser, V.H. (1982) Ecological Forest Site Classification. Journal of Forestry, 80, 493-498.

[17] Simpson, E.H. (1949) Measurement of Diversity. Nature, 163, 688. http://dx.doi.org/10.1038/163688a0

[18] Ward, J.R. (1992) Woody Vegetation of Dry, Sandy Uplands of Eastern Texas. Texas Journal of Science, 44, 32833294.

[19] Barnes, B.V. (1998) Forest Ecology. John Wiley and Sons Inc., Hoboken, 773 p.

[20] Gegout, J. and Houllier, F. (1992) Canonical Correspondence Analysis for Forest Site Classification. Annales des Sciences Foresteries, 53, 5981-5990.

[21] Klinka, K., Krajina, V.J., Ceska, A. and Scagel, A.M. (1989) Indicator Plants of Coastal British Columbia. University of British Colombia Press, Vancouver, 288 p. 


\section{Submit or recommend next manuscript to SCIRP and we will provide best service for you:}

Accepting pre-submission inquiries through Email, Facebook, LinkedIn, Twitter, etc.

A wide selection of journals (inclusive of 9 subjects, more than 200 journals)

Providing 24-hour high-quality service

User-friendly online submission system

Fair and swift peer-review system

Efficient typesetting and proofreading procedure

Display of the result of downloads and visits, as well as the number of cited articles

Maximum dissemination of your research work

Submit your manuscript at: http://papersubmission.scirp.org/ 